\title{
Experimental investigation of drying of malt bagasse
}

\author{
Zorzi, B. D..$^{\text {; }}$ Machry, K. ${ }^{\text {a }}$ Krolow, P. ${ }^{\text {; }}$ Moura, C. M..$^{\text {; }}$ Oliveira, E. G. ${ }^{\text {b }}$ Rosa, G. S. ${ }^{a^{*}}$ \\ ${ }^{a}$ Chemical Engeneering, Federal University of Pampa, Bagé, Brazil \\ ${ }^{\mathrm{b}}$ Food Engeneering, Federal University of Pampa, Bagé, Brazil
}

*E-mail of the corresponding author: gabrielarosa@ unipampa.edu.br

\begin{abstract}
The aim of this work was to investigate the convective drying process of malt bagasse and to evaluate the influence of this process on the application of this residue as adsorbent in methylene blue removel by adsorption process. The experimental system for drying was a fixed bed dryer with parallel airflow, with operating conditions: air temperature in the range of 40 to $90^{\circ} \mathrm{C}$ and air veocity of $2 \mathrm{~m} / \mathrm{s}$. The adsorption experiments were perfomed with solution of methylene blue at 70 ppm concentration. The drying kinetics showed a constant drying rate period followed by a falling drying rate. The results obtained for the dye removal efficiency were $56 \%$ for in natura sample and in the range of $81.69 \%$ to $93.99 \%$ for dried samples.
\end{abstract}

Keywords: dryin; malt bagasse; adsorption 


\section{Introduction}

Nowadays, environmental problems and energy demands have demanded the search for energies renewable and clean. The use of biomass is part of the concept of sustainable development, besides reducing costs and not harming the environment [1]. Adsorption is a unit operation commonly used to separate solid-liquid, and can be efficient and low cost, using different adsorbents [2]. Solid residues from the agroindustry, such as sugarcane bagasse, coconut mesocarp and wood sawdust, are available in large quantities and can be considered as potential adsorbents due to their low cost due to not receiving any previous treatment and their physical- chemical properties [3].

In the process of brewing many solid wastes are generated, such as malt bagasse. Acording to Ferrari [4], the malt bagasse is the main byproduct resulting from the fermentation process formed by the solid part of the filtration of the fermentation must before boiling. One of the applications of the malt bagasse is the use as low-cost biosorbent in the sorption of dyes. These residues have limitation related to their high moisture content, which has a negative influence on transport, storage and for applications. Thus, the drying of malte bagasse is the first step for the biomass preparation. Piffer et al. [5] studied the adsorption of textile dye on malt bagasse in order to evaluate the efficiency of the process and Zanette et al.[6] reported the adsorption of $5 \mathrm{G}$ blue dye using the malt bagasse, verifying the influence of the agitation speed in the process.

The aim of this work was to investigate the convective drying process of malt bagasse and to evaluate the influence of this process on the application of this residue as adsorbent in removal efficiency of methylene blue by adsorption process.

\section{Materials and Methods}

The raw material was supplied from artisanal beer producers from Bagé, Rio Grande do Sul, Brazil, and was packed in plastic bags at $-18{ }^{\circ} \mathrm{C}$ until analysis. The moisture content was determined by the oven method at $105^{\circ} \mathrm{C}$ for $24 \mathrm{~h}$.

Figure 1 illustrates the experimental system used in the drying experiments. The experimental system involved a fixed bed dryer. The air flow coming from the blower [a] was monitored by psychrometer $[\mathrm{b}]$ and was heated by an electrical heater (c). Measurements of air velocity were performed by an anemometer [f]. In order to monitor mass of samples during the drying experiments a digital balance [e] was used, connected with a tray in the drying chamber. 


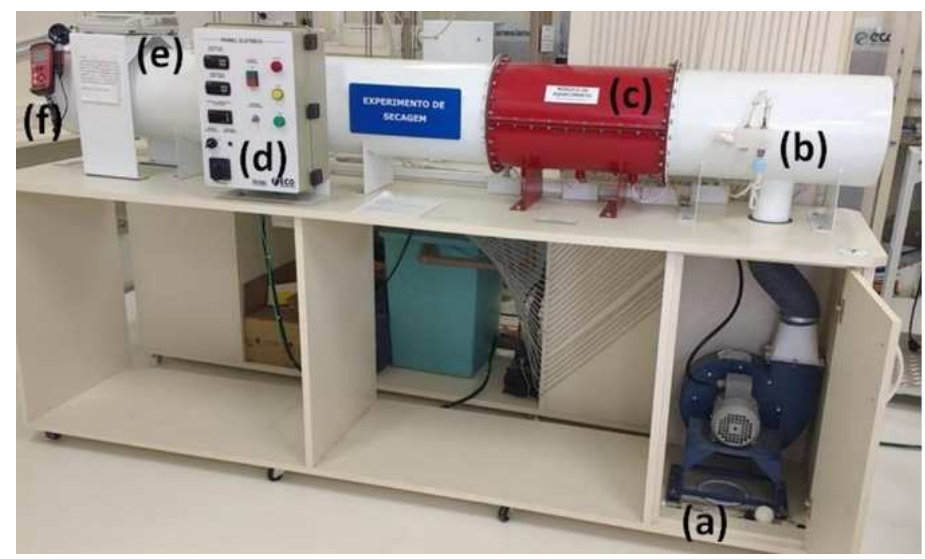

Fig. 1 Experimental system.

The malt bagasse samples were distributed uniformly as a thin layer onto the stainless steel tray of size $12 \times 0.5 \mathrm{~cm}$ and dried. The ranges of operating conditions were defined in preliminary tests. The inlet air temperature $\left(T_{a i r}\right)$ were $40,60,75$ and $90{ }^{\circ} \mathrm{C}$ and air velocity $\left(v_{\text {air }}\right)$ was $2 \mathrm{~m} / \mathrm{s}$. Drying curves $\left(\left(M-M_{e}\right) /\left(M_{0}-M_{e}\right)\right.$ as a function of time) were obtained and the equilibrium moisture content was assumed as the final moisture content, when the drying rate was practically null, for each drying condition.

The calibration curve of methylene blue dye was obtained from different concentrations and their respective absorbances in UV-VIS spectrophotometer at the wavelength of $664 \mathrm{~nm}$. The calibration curve obtained for methylene blue is presented in Equation 1.

$$
A B S=0,1175[M B]
$$

where $[\mathrm{MB}]$ corresponds to the concentration of the dye in ppm and abs the absorbance.

The adsorption process was performed in a batch system. $2 \mathrm{~g}$ of the malt bagasse in natura and dried were first placed in a Erlenmeyer flask. $50 \mathrm{~mL}$ of methyle blue solution at a concentration of $70 \mathrm{ppm}$ was added to the flask. The mixture were stirred continuously using a shaker at speed of $150 \mathrm{rpm}$ for $60 \mathrm{~min}$ in a constant temperature at $25^{\circ} \mathrm{C}$. After adsorption, each sample containing the solution and adsorbent was subjected to centrifugation at 3000 rmp for $10 \mathrm{~min}$. Then, the concentration of methylene blue were measured using UV-VIS spectrophotometer. The removal efficiency of methylene blue (\% Rem) was determined using the Equation 2.

$$
\% \operatorname{Rem}=\frac{C_{0}-C_{e q}}{C_{o}} \times 100
$$

where $\mathrm{Co}$ is the initial concentration of the dye, $\mathrm{C}_{\mathrm{eq}}$ is the final concentration.

Experimental data were analyzed by Statistica 7.1 software. Mean comparasions were carried out by Tukey test ( $\mathrm{p}<0.05$ was considered as significant). 


\section{Results and discussion}

Figure 2 shows the typical drying curves obtained for malt bagasse.

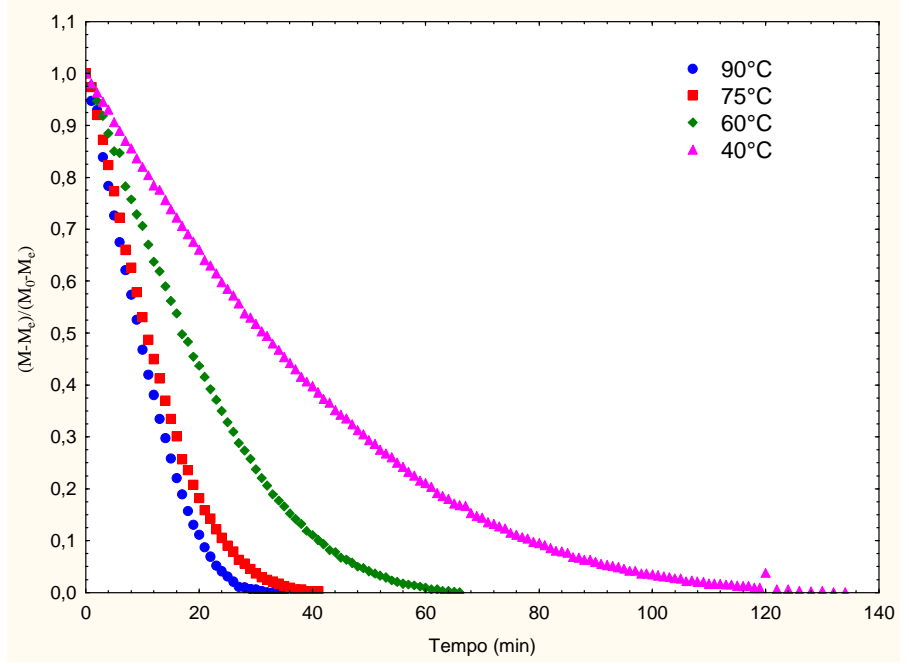

Fig. 2 Drying kinetics at different operation conditions.

In all experiments, the drying kinetics showed a constant drying rate period followed by a falling drying rate period. As expected, an increase in air temperature also significantly increased the drying kinetics and resulted in lower final moisture contents. The moisture content for in natura malt was $74.25 \% \pm 0.43$ ( $\%$ w.b.) and after the drying process the results were in the range of 2.6 to $6.9 \%$, similar with results showed by Gonçalves et al. [7]. According to Lopes et al. [8] the final moisture content of the material is directly related to the drying time and temperature. According to Wang and Chen [9] the temperature and moisture content of the material play a very important role in the heat and mass transfers during the drying. At lower temperatures it was necessary a longer time for the removal of water from the material because, according to Vilela and Silva [10], drying requires gradients that help as the driving force for the mass flow of water into the air drying.

Table 1 shows the results to the removal efficiency of the methylene blue dye using malt bagasse samples before and after drying.

Table 1. Removal efficiency of methylene blue.

\begin{tabular}{|c|c|c|c|c|c|}
\hline & in natura & & Dried & amples & \\
\hline & & $40^{\circ} \mathrm{C}$ & $60^{\circ} \mathrm{C}$ & $75^{\circ} \mathrm{C}$ & $90^{\circ} \mathrm{C}$ \\
\hline $\operatorname{Rem}(\%)$ & $56.00 \pm 0.87^{\mathrm{a}}$ & $93.60 \pm 0.25^{b}$ & $93.71 \pm 0.26^{b}$ & $93.48 \pm 0.13^{b}$ & $93.99 \pm 0.32^{b}$ \\
\hline
\end{tabular}

Average \pm deviation $(n=3)$

Different letters indicate significant differences between samples $(\mathrm{p}<0.05)$ 
It can be observed that drying of the adsorbent material favored the adsorption process because it allowed the reduction of moisture content of the adsorbent material, and, consequently, the increase of the intraparticle porosity and adsorption sites as mentioned by Geankoplis [11] and Arim et al. [12]. There were no significant difference $(\mathrm{p}<0.05)$ between the removal efficiency using dried samples at differents conditions. Then, the results indicated that the adequate drying condition for malt bagasse is at $90{ }^{\circ} \mathrm{C}$, since the drying can be faster with lower cost of energy.

\section{Conclusion}

The malt bagasse drying showed a constant drying rate period followed by falling drying rate period, wich is typical of materials with high moisture content. The dried malt bagasse showed to be efficient in the removal efficiency of methylene blue, with no significant difference between samples dried at differents temperatures. The results showed promising results, and it was possible to affirm that malt bagasse can be used as adsorbent for adsorption of dye, reducing the environmental impact and showing a new application for this residue.

\section{References}

[1] Cordeiro, L.G. Caracterização e Viabilidade Econômica do Bagaço de Malte Oriundo Cervejarias Para Fins Energéticos. Dissertação de Mestrado. Universidade Federal da Paraíba. 2011.

[2] Oliveira, L.H.; Arraes, D.D.; Gomes, G.E.; Lima, A.E.O.; Ramos, P.H. Estudo Da Adsorção Do Corante Rodamina B Em Argila Natural. $10^{\circ}$ Encontro Brasileiro Deadsorção. Guarujá -Sp, 2014.

[3] Matos, T.T.S.; Jesus, A.M.D.; Araújo, B.R.; Romão, L.P.C.; Santos, L.O.; Santosa, J.M. Aplicação De Subprodutos Industriais Na Remoção De Corantes Reativos Têxteis. Revista Virtual Química, V.5, Pp. 840-852, 2013.

[4] Ferrari, V. O Mercado De Cerveja No Brasil. Dissertação De Mestrado. Univerdidade Católica Do Rio Grande Sul, 2008. XII Congresso Brasileiro de Engenharia Química Em Iniciação Científica Ufscar - São Carlos - SP 16 a 19 de Julho de 2017.

[5] Piffer, H.H.; Juchen, P.T.; Veit, M.T.; Fagundes-Klen, M.R.; Palácio, S.M.; Gonçalves, G.C. Estudo Da Dessorção Do Corante Têxtil Reativo Azul 5g Adsorvido Em Bagaço De Malte. In: Anais Do Xi Congresso Brasileiro De Engenharia Química Em Iniciação Científica. São Paulo: Blucher, 2015.

[6] Zanette, J.C.; Piffer, H.H.; Veit, M.T. Biossorção Do Corante Têxtil Azul 5g Utilizando O Bagaço De Malte. In: Anais Do I Encontro Anual De Iniciação Científica, Tecnológica E Inovação. Santa Catarina, 2015.

[7] Gonçalves, C. ; Echevarria, E.R. ; Rosa, G.S. ;Oliveira, E.G.; Biossorção De Corante Catiônico Utilizando O Bagaço De Malte. Anais Do Xxi Congresso Brasileiro De Engenharia Química, Fortaleza, 2016 
[8] Lopes, C.R.; Queiroz, A. M.; Silva, K. C.; Mendes, E. C. S.; Silvério, B.C.; Ferreira,M. M. P.; Estudo Cinético De Desidratação E Caracterização Do Bagaço De Malte Resíduo Da Indústria, P. 2697-2702. In: Anais Do Xi Congresso Brasileiro De Engenharia Química Em Iniciação Científica. São Paulo: Blucher, 2015.

[9] Wang, Z.H.; Chen, G. Heat And Mass Transfer In "Xed-Bed Drying. Chemical Engineering Science 54 (1999) 4233 \}4243, Kowloon, Hong Kong, 1999

[10] Vilela, F.A.; Silva, W. R. Efeitos Da Secagem Intermitente Sobre A Qualidade De Sementes De Miho.P. 185-209. In: Anais Esalq. Piracicaba, 1991.

[11] Geankoplis, C.J. Procesos De Transporte Y Operaciones Unitarias. $3^{\circ}$ Edição, México: Cecsa, 1998

[12] Arim, A.L.; Mesquita, V.R.; Echevarria, E.R.; Lima, D.R.; Morais, M.M.; Rosseto,V.; Almeida, A.R.F.; Rodrigues, L.M. Investigação Do Bagaço De Butiá Quaraimana Comomaterial Adsorvente Alternativo Para O Tratamento De Efluentes. In: Anais Do $10^{\circ}$ Encontro Brasileirosobre Adsorção. São Paulo, 2014.

[13] Barbosa, R.M. Contribuição Do Mercado De Carbono Para A Viabilidade De Projetos De Eficiência Energética Térmica E De Troca De Combustíveis Em Cervejarias. Dissertação De Mestrado. Universidade De São Paulo, 2010.

[14] Brasil. Ministério Da Agricultura, Pecuária E Abastecimento. Portaria No 166 De 12 De Abril De 1977. Padronização, Classificação E Comercialização Do Malte Cervejeiro Ou Cevada Malteada Para Fins Cervejeiros.

[15]Foust, A.S.; Wenzel, L.A.; Clump, C.W.; Maus, L.; Andersen, L.B. Princípios Das Operações Unitárias. Rio De Janeiro, Guanabara Dois, 1982. 670 p. 